\title{
Analisis Tagline Merek yang Mengandung Unsur Pornografi di Media Sosial
}

\author{
Inda Nurdahniar \\ Fakultas Hukum, Universitas Langlangbuana \\ Correspondence email: indanurdania@yahoo.com
}

\begin{abstract}
Abstrak. Merek memiliki nilai ekonomis sehingga diperlukan adanya perlindungan. Perlindungan merek timbul ketika didaftarkan. Tetapi hal ini dikecualikan terhadap merek yang mengandung unsur kesusilaan. Pada kenyataannya banyak pelaku usaha yang menggunakan merek dengan kata, logo ditambah tagline yang mengandung unsur pornografi. Permasalahannya terlihat jika merek tersebut tetap beroperasi ditengah-tengah masyarakat bahkan merambah ke media sosial. Berdasarkan hasil penelitian, pengaturan tentang tagline merek mengandung unsur pornografi di media sosial tidak diatur secara khusus tetapi tersebar diberbagai peraturan perundang-undangan dan terlihat adanya overlapping. Pada kenyataannya akun @ ngocok.eskopi dengan merek dagang "Ngocok Es Kopi" lolos sebagai merek terdaftar. Padahal bila dilihat secara kesuluruhan, baik merek, logo dan tagline yang digunakan di media sosial telah memberikan persepsi atau gambaran pornografi secara implisit. Di era digitalisasi, media sosial merupakan media yang potensial untuk sarana promosi, sudah sepatutnya ada pengaturan khusus seperti promosi secara konvensional. Berbagai peraturan pun harus saling terintegrasi misalnya penggunaan akun di media sosial menggunakan identitas legal (KTP), memaksukan tagline sebagai definisi merek pada aturan induknya yaitu UU MIG, lolosnya merk yang terdaftar merupakan tanggungjawab dari pemberi regulasi (faktor manusia) dan tidak boleh dibebankan pada sistem semata (faktor teknologi), memperluas batasan pornografi menjadi eksplisit dan implisit.
\end{abstract}

Kata Kunci: Tagline; Merk; Pornografi; Media Sosial

\begin{abstract}
Brands have economic value so protection is needed. Brand protection arises when registered. But this is excluded against brands that contain elements of decency. In reality many businesses use brands with the word, logo plus taglines that contain pornographic elements. The problem is seen if the brand continues to operate in the middle of society and even penetrated into social media. Based on the results of the study, the arrangement of brand taglines containing pornographic elements on social media is not specifically regulated but spread across various laws and regulations and there is overlapping. In fact the @ngocok.eskopi account with the trademark "Ngocok Es Kopi" passes as a registered trademark. Whereas when viewed with great disalness, both brands, logos and taglines used on social media have given implicit perceptions or images of pornography. In the era of digitization, social media is a potential media for means of promotion, it is fitting that there are special arrangements such as conventional promotion. Various regulations must also be integrated, such as the use of accounts on social media using legal identity (KTP), applying the tagline as a brand definition in the parent rule of the MIG Law, the passing of registered brands is the responsibility of regulators (human factors) and should not be charged to the system alone (technological factors), expanding the limitations of pornography to be explicit and implicit.
\end{abstract}

Keywords: Tagline; Brand; Pornography; Social Media

\section{PENDAHULUAN}

Praktek bisnis, banyak sekali produk yang ditawarkan dan satu sama lain saling bersaing untuk menarik minat konsumen. Berbagai cara dilakukan oleh pelaku usaha, salah satunya dengan membuat tanda pada produk yang ditawarkannya. Tanda ini bisa berupa kata, gambar, simbol, logo, huruf, warna atau bahkan kombinasi dari apa yang disebutkan, sehingga menciptakan suatu tanda khusus yang mana tanda ini akan menjadi pembeda antara produk yang satu dengan produk lainnya. Biasanya tanda ini disebut sebagai merek. Salah satu fungsi dari merek ditujukan untuk memudahkan konsumen mengidentifikasi produk tersebut dipasaran.

Merek memiliki nilai ekonomis yang memerlukan suatu perlindungan hukum, dimana tidak ada pihak lain yang dapat menggunakan merek tersebut. Pada dasarnya, perlindungan merek di Indonesia telah diatur dalam
Undang-Undang Nomor 20 Tahun 2016 tentang Merek dan Indikasi Geografis (Selanjutnya disingkat UU MIG). UU MIG menganut sistem konstitutif artinya perlindungan merek didapatkan setelah dilakukannya pendaftaran oleh pemilik merek yang beritikad baik. Akan tetapi, merek tidak dapat didaftar jika merek tersebut bertentangan dengan ideologi negara, peraturan perundang-undangan, moralitas, agama, kesusilaan, atau ketertiban umum.

Pada kenyataannya tidak sedikit pelaku usaha membuat merek dengan kata dan gambar yang unik, "kekinian" atau bahkan "nyeleneh". Banyak diantara mereka menganggap bahwa hal tersebut justru lebih menarik rasa penasaran konsumen, agar mau membeli produknya. Beberapa merek tersebut justru mengandung unsur pornografi secara tidak langsung atau tersirat.

Salah satu contoh merek tersebut yaitu "Ngocok Es Kopi" dengan beberapa slogan (tagline) dalam 
kemasannya seperti "tegang? ngocok aja dulu", "mau ngocok atau dikocokin", "ngocok bikin ketagihan", "ngocok sama mantan katanya lebih berkesan" dan "80 Juta, bisa ngocok berapa kali". Tagline terakhir diduga merujuk pada kasus prostitusi yang dilakukan oleh artis Indonesia berinsial VA pada tahun 2019, yang menerima uang sejumlah 80 juta. ${ }^{1}$ Produk minuman bermerek "Ngocok Es Kopi" ini dipromosikan dalam media sosial. Hal ini tidak mengherankan, mengingat banyak sekali pelaku usaha yang membuat akun di media sosial hanya untuk kepentingan usaha. Dari hal tersebut, peneliti melihat adanya permasalahan yaitu ketika mereka tersebut ditolak atau tidak didaftarkan tetapi keberadaan merek itu tetap hadir ditengah masyarakat (beroperasi) atau bahkan tetap melakukan promosi di media sosial. Bagaimanakah pengaturan terutama mengenai pengawasannya, mengingat dewasa ini promosi bisa dilakukan secara offline maupun online. Apakah peraturan tentang hal tersebut tumpang tindih (overlapping) sehingga memunculkan ketidakpastian yang berimplikasi pada maraknya penggunaan atau keberadaan merek (berserta tagline sebagai sarana promosi) dengan unsur pornografi baik secara langsung maupun tidak langsung.

\section{Tinjauan Teori \\ Pornografi}

Istilah "pornography" ini sendiri sebenarnya berasal dari istilah Yunani yang berarti "writing about prostitutes". Sejarah pornografi sebenarnya berawal dari kebiasaan para pejabat Romawi yang pada saat itu menyenangi patung, lukisan atau gambaran yang berasosiasi seksual dengan tujuan meningkatkan gairah seksual. ${ }^{2}$ Didalam Black's Law Dictionary istilah "pornography" di artikan sebagai "material (such as writings, pornographs, or movies) depicting sexual activity or erotic behavior in a way that is designed to arouse sexual excitement.". Dengan kata lain, Black's Law Dictionary yang menekankan 3 faktor utama yaitu 1) Materi: material (such as writings, pornographs, or movies), 2) sifat materi: depicting sexual activity or erotic behaviour dan 3) Kualifikasi sebagai tujuan pembuatan materi, designed to arouse sexual excitement. ${ }^{3}$ Sejalan dengan hal tersebut, menurut Kamus Besar Bahasa Indonesia (selanjutnya disingkat KBBI) pornografi adalah penggambaran tingkah laku

\footnotetext{
${ }^{1}$ Yudha Wirawanda, et.all., Bias Gender dalam Berita
} Kasus Vanessa Angel (Analisis Wacana Kritis Sara Mills dalam detik.com)., Channel Jurnal Komunikasi, Volume 7, Nomor 1, April 2019, hlm. 13.

${ }^{2}$ Hwain Cristiano, Norma Kesusilaan sebagai Batasan Pornografi menurut UU No. 44 Tahun 2008, Jurnal Hukum Pembangunan Tahun ke-40 No.1 Januari-Maret 2010, hlm. 40.

${ }^{3} \mathrm{Id}$, hlm. 41. secara erotis dengan lukisan atau tulisan untuk membangkitkan nafsu berahi. ${ }^{4}$

Berdasarkan Pasal 1 Angka 1 Undang-Undang Nomor 44 Tahun 2008 tentang Pornografi (selanjutnya disingkat UU Pornografi), "Pornografi adalah gambar, sketsa, ilustrasi, foto, tulisan, suara, bunyi, gambar bergerak, animasi, kartun, percakapan, gerak tubuh, atau bentuk pesan lainnya melalui berbagai bentuk media komunikasi dan/atau pertunjukkan di muka umum, yang memuat kecabulan atau eksploitasi seksual yang melanggar norma kesusilaan dalam masyarakat."

Unsur rumusan "pornografi" terdiri dari:

1. Obyek, berupa gambar, sketsa, ilustrasi, foto, tulisan, suara, bunyi, gambar bergerak, animasi, kartun, percakapan, gerak tubuh, atau bentuk pesan lainnya;

2. Syarat kualifikasi obyek: memuat kecabulan / eksploitasi seksual yang melanggar norma kesusilaan dalam masyarakat;

3. Publisitas: melalui berbagai bentuk media komunikasi dan/atau pertunjukan di muka umum.

Rumusan di atas dibandingkan dengan rumusan definisi pornografi menurut Black's Law Dictionary akan tampak bahwa UU Pornografi lebih memberikan batasan yang sifatnya memperkecil ruang lingkup pornografi. Seperti diketahui Black's Law Dictionary memahami Pornografi sebagai semua materi yang bermuatan seksual dengan tujuan untuk meningkatkan atau menimbulkan nafsu seksual bagi penikmatnya sedangkan Pasal 1 Angka 1 UU Pornografi lebih memberikan pengaturan semua materi yang berisikan eksploitasi seksual dan di publikasikan. ${ }^{6}$

Lebih lanjut, dalam rumusan Pasal 1 Angka 1 diatas, dijelaskan pula adanya unsur publisitas melalui berbagai bentuk media komunikasi. Dewasa ini bentuk media komunikasi dapat diberupa media cetak (offline) maupun media internet (online).

Pesatnya perkembangan teknologi informasi serta mudahnya akses terhadap internet, telah membuka mata kita untuk melakukan penggalian informasi tanpa batas. Dalam kemajuan teknologi tersebut mempermudah akses menuju era digitalisasi. Namun pemanfaatan kemudahan informasi juga dimanfaatkan oleh pihak yang tidak bertanggung jawab dengan meyebarluaskan pornografi melalui internet. Pornografi menjadi suatu persoalan yang dihadapi oleh bangsa Indonesia pada era globalisasi saat ini, karena perkembangan pornografi bukan hanya terjadi terhadap kehidupan sosial di masyarakat, bahkan penyebarannya secara luas di dunia

${ }^{4}$ Sultan Himawan, Representasi Pornografi Pada Media Sosial (Analisis Semiotika Pierce Pada Aplikasi Bigo Live), MediaKom Jurnal Ilmiah Ilmu Komunikasi, Volume 8 Nomor 1, 2018, hlm. 81.

$$
5 \text { Id, hlm. } 46 .
$$

${ }^{6} \mathrm{Id}$, hlm. 47. 
maya pun terus menjadi suatu hal yang sangat wajar bagi sebagian masyarakat. ${ }^{7}$

Berdasarkan Pasal 4 Ayat 1 UU Pornografi, "Setiap orang dilarang memproduksi, membuat, memperbanyak, menggandakan, menyebarluaskan, menyiarkan, mengimpor, mengekspor, menawarkan, memperjualbelikan, menyewakan, atau menyediakan pornografi yang secara eksplisit memuat:

a. persenggamaan, termasuk persenggamaan yang menyimpang;

b. kekerasan seksual;

c. masturbasi atau onani;

d. ketelanjangan atau tampilan yang mengesankan ketelanjangan;

e. alat kelamin; atau

f. pornografi anak

Pasal tersebut, peneliti berpendapat bahwa batasan perbuatan pornografi harus berwujud secara tegas, terang-terangan atau gamblang. Dengan kata lain, pengaturan dalam pasal ini tidak mencangkup segala perbuatan yang mengandung unsur pornografi secara implisit. Padahal banyak sekali perbuatan yang menimbulkan persepsi atau gambaran dan lebih jauh dapat membangkitkan gairah seksual. Tidak sedikit pula hal ini digunakan sebagai daya tarik dalam suatu produk. Di dalam pornografi terkandung unsur pemberontakan terhadap tatanan seksualitas yang mapan seperti ketelanjangan merupakan hal yang bersifat rahasia bagi individu tetapi menjadi berubah manakala pornografi ini memahami berbeda dengan melakukan perbuatan telanjang di depan umum dengan pose atau gaya yang melecehkan atau tidak menghargai harkat dan martabat manusia. Pada kondisi inilah, perbuatan pronografi jelas telah melanggar norma kesusilaan sebagai bentuk perbuatan yang asusila. Jadi didapatkan satu pemahaman mendasar bahwa pornografi itu merupakan salah satu bentuk perbuatan yang pada hakekatnya melanggar nilai kepatutan dan moralitas dalam masyarakat. ${ }^{8}$ Mengingat sumber norma kesusilaan itu dari hati nurani manusia secara pribadi, maka pertimbangan dan ukuran nilai kesusilaan itu sebenarnya tidak bersifat subyektif tetapi universal. Jika manusia secara pribadi memahami dan mengakui satu bentuk nilai-nilai dasar atas moral, harkat dan martabat manusia (nilai susila) maka sebenarnya nilai ini pun juga dihayati secara sama oleh manusia secara umum. ${ }^{9}$

\section{Merek dan Tagline Mengandung Unsur Pornografi Berdasarkan Peraturan Perundang-Undangan}

7 Suratman et.all., Analisis Yuridis Penyidikan Tindak Pidana Pornografi Berdasarkan Undang-Undang Nomor 44 Tahun 2008 di Era Digitalisasi, Jurnal Pembaharuan Hukum Volume I No. 2 Mei - Agustus 2014, hlm. 170.

8 Supra note 3, hlm. 39.

${ }^{9}$ Id.
Hak Atas Merek merupakan lingkup Hak Atas Kekayaan Intelektual karena hak atas merek sebagai hak untuk memakai tanda atau merek guna membedakan suatu produk dagang seseorang dengan produk dagang orang lain, walaupun tidak memiliki unsur pokok seperti yang diartikan dengan pengertian milik intelektual, yaitu tidak ada unsur usaha intelektual dalam bentuk penciptaan atau penemuan. Namun demikian terdapat persamaan antara hak cipta, hak paten dan hak merek dilihat dari sifat atau bentuk haknya yaitu hak atas benda yang tidak berwujud. ${ }^{10}$

Merek adalah salah satu bagian dari wujud karya intelektual memiliki peranan penting bagi kelancaran dan peningkatan perdagangan barang atau jasa dalam kegiatan perdagangan dan investasi yang terjadi pada perkembangan globalisasi sekarang ini. ${ }^{11}$ Peran merek dalam dunia pemasaran sangat penting, karena publik sering mengkaitkan suatu kualitas atau reputasi barang dan jasa dengan merek tertentu. Merek juga harus memiliki daya pembeda yang cukup, artinya memiliki kekuatan untuk membedakan barang atau jasa produk suatu perusahaan lainnya. ${ }^{12}$ Bahkan banyak dari pelaku usaha menambahkan tagline atau slogan untuk memberikan ciri yang lebih khusus pada merknya.

Melalui merek, masyarakat sebagai konsumen akan dengan mudah mengenali suatu produk perusahaan tertentu. Merek biasanya dicantumkan pada barang atau pada kemasan atau bungkusan barang yang dijual atau dicantumkan secara tertentu pada hal-hal yang terkait dengan jasa yang dijual. ${ }^{13}$

Berdasarkan Pasal 1 Angka 1 UU MIG, "Merek adalah tanda yang dapat ditampilkan secara grafis berupa gambar, logo, nama, kata, huruf, angka, susunan warna, dalam bentuk 2 (dua) dimensi dan/atau 3 (tiga) dimensi, suara, hologram, atau kombinasi dari 2 (dua) atau lebih unsur tersebut untuk membedakan barang dan atau jasa yang diproduksi oleh orang atau badan hukum dalam kegiatan perdagangan barang dari/atau jasa". Menuruf Prof. Imas Rosidawati, di sebagian negara, slogan iklan, warna tunggal, tanda tiga dimensi (bentuk produk atau kemasan), tanda-tanda yang dapat didengar (bunyi) atau tanda olfactory (bau) juga dianggap sebagai merek. Dengan kata lain, pengertian merek dalam pasal diatas

10 Sulastri, et.all., Perlindungan Hukum Terhadap Merek (Tinjauan Terhadap Merek Dagang Tupperware Versus Tulipware), Jurnal Yuridis Vol. 5 No. 1, Juni 2018, hlm. 161.

${ }^{11}$ Rahmadia Maudy Putri Karina, et.all., Perlindungan Hukum Bagi Pemegang Hak Merek Dagang Ikea Atas Penghapusan Merek Dagang, Jurnal Pembangunan Hukum Indonesia, Volume 1, Nomor 2, Tahun 2019, hlm. 195.

${ }^{12}$ Iffan Alif Khoironi, Implementasi Pendaftaran Merk Sebagai Bentuk Perlindungan Hukum Pada Home Industry Eegroll, Unnes Law Journal Volume 2 Nomor 2, Tahun 2013, hlm. 130.

${ }^{13}$ Yayuk Sugiarti, Perlindungan Merek Bagi Pemegang Hak Merek Ditinjau Dari Undang-Undang Nomor 15 Tahun 2001 Tentang Merek, Jurnal Jendela Hukum, Volume 3, Nomor 1, April 2016, hlm. 33. 
menunjukkan bahwa tagline atau slogan belum dapat dikatakan sebagai merek. Padahal menurut peneliti, tagline atau slogan sangat erat kaitannya dengan merk bahkan dapat pula menjadi factor pembeda, seyogyanya merk masuk dalam pengertian merk dalam aturan induknya yaitu UU MIG.

Berdasarkan Pasal 1 Angka 5 UU MIG, "Hak atas Merek adalah hak eksklusif yang diberikan oleh negara kepada pemilik Merek yang terdaftar untuk jangka waktu tertentu dengan menggunakan sendiri Merek tersebut atau mernberikan izin kepada pihak lain untuk menggunakannya”. Jadi pemilik merek terdaftarlah yang berhak menggunakan sebuah merek. Hak atas merek diperoleh setelah proses pendaftaran dilakukan. Tidak semua merek yang mengajukan pendaftaran akan diterima. Ada batasan-batasan merek yang pendaftarannya bisa diterima. ${ }^{14}$

Berdasarkan Pasal 20 Huruf a UU MIG, "Merek tidak dapat didaftar jika bertentangan dengan ideologi negara, peraturan perundang-undangan, moralitas, agama, kesusilaan, atau ketertiban umum”. Dengan kata lain, setiap merek menampilkan wujud reputasi yang bernilai moral, material, dan komersial. ${ }^{15}$ Intinya sebuah merek yang mengadung unsur kesusilaan tidak dapat didaftarkan, namun persoalan muncul manakala merek tersebut tetap digunakan dalam praktek bisnis. Artinya tidak ada tindakan lebih lanjut khususnya dari Direktorat Jenderal Kekayaan Intelektual (selanjutnya disingkat DJKI) karena hal ini bukan kompentensi dari DJKI (kecuali DJKI memberikan hak merek seperti kasus pencabutan merek Buddha Bar ). Menurut peneliti, lolosnya merk merupakan tanggungjawab dari pemberi regulasi (factor manusia) dan tidak bisa sepenuhnya dibebankan pada system (teknologi). Di awal telah dijelaskan pengertian dari merek, merek sendiri terdiri dari merek dagang dan merek jasa. Merek dagang merujuk pada barang yang diperdagangkan sementara merek jasa merujuk pada jasa (pelayanan) yang diperdagangkan. Sementara, Pasal 10 Ayat 1 Huruf a Peraturan Badan Pengawas Obat dan Makanan Nomor 31 Tahun 2018 tentang Label Pangan Olahan (selanjutnya disingkat Peraturan BPOM), istilah yang digunakan bukanlah merek dagang melainkan nama dagang. Lebih lanjut, berdasarkan Pasal 12 Ayat 1 Huruf a Peraturan BPOM, nama dagang tidak dapat digunakan bila memuat unsur yang bertentangan dengan ketentuan peraturan perundang-undangan, moralitas agama, budaya, kesusilaan, dan/atau ketertiban umum.

Tagline atau slogan adalah kalimat pendek yang memiliki arti dan biasanya melekat tak terpisahkan pada suatu merk sebagai bagian dari pemasaran suatu produk. Darno mengemukakan jika tagline memiliki 3 indikator

14 Rakhmita Desmayanti, Tinjauan Umum Perlindungan Merk Terkenal Sebagai Daya Pembeda Menurut Perspektif Hukum di Indonesia, Jurnal Cahaya Keadilan . Vol. 6. No. 1, Tahun 2018, hlm. 14.

${ }^{15}$ Supra note 13, hlm. 32. sebagai berikut: Familiarity adalah tagline yang mudah diingat dan dimengerti oleh konsumen, differentiation adalah ciri khas yang membedakan dengan merek lainnya, messeger of value adalah sejauh mana efek pesan iklan yang disampaikan itu dapat menarik perhatian konsumen. ${ }^{16}$

Tagline juga merupakan salah satu metode promosi yang sering digunakan dalam iklan suatu produk merek. Tagline biasanya menggunakan kata atau kalimat yang unik, sehingga tak heran jika konsumen selalu mengucapkan dan mengingat tagline dari suatu merek. Jika konsumen mengingat tagline suatu merek maka secara bersamaan konsumen juga akan mengingat merek tersebut ${ }^{17}$ Menurut peneliti, tagline merupakan bagian dari merek karena tagline dapat memberikan ciri khas tertentu yang melekat erat (tidak terpisah) dalam suatu merek. Lebih lanjut tagline merupakan sarana promosi merek dalam bentuk iklan melalui offline maupun online untuk menarik minat konsumen.

Berdasarkan uraian diatas, peneliti berpendapat bahwa tagline adalah bagian dari merek, dimana tagline sering digunakan oleh pelaku usaha sebagai sarana promosi dalam bentuk iklan baik melalui media offline maupun online untuk menarik minat konsumen. Pengaturan tentang tagline $\mathrm{di}$ Indonesia tersebar diberbagai peraturan perundang-undangan. Peneliti memfokuskan pembahasan pada pengaturan tagline yang mengandung unsur pornografi.

Beberapa peraturan yang akan disajikan yaitu Undang-Undang Nomor 8 Tahun 1999 tentang Perlindungan Konsumen (selanjutnya disingkat UUPK), Peraturan Pemerintah Nomor 69 Tahun 1999 tentang Label dan Iklan Pangan (Selanjutnya disingkat PP LIP), Peraturan BPOM, Undang-Undang Nomor 32 tahun 2002 tentang Penyiaran (selanjutnya disingkat UU Penyiaran), dan Undang-Undang Nomor 11 tahun 2008 tentang Informasi dan Transaksi Elektronik (selanjutnya disingkat UU ITE).

Berdasarkan Pasal 1 UUPK, "Promosi adalah kegiatan pengenalan atau penyebarluasan informasi suatu barang dan/atau untuk menarik minat beli konsumen terhadap barang dan atau jasa yang akan dan sedang diperdagangkan." Lebih lanjut Pasal 17 huruf $\mathrm{f}$ UUPK menyatakan "Pelaku usaha periklanan dilarang memproduksi iklan yang melanggar etika dan atau ketentuan perundang-undangan mengenai periklanan". Peneliti melihat adanya kerancuan atas frase "pelaku usaha periklanan" karena senyatanya kini iklan bisa dibuat secara langsung oleh pelaku usaha yang bersangkutan.

16 Darno (dalam Derby Juliana Osak), Derby Juliana Osak, et.all., Pengaruh Brand Ambassador Dan Tagline Terhadap Keputusan Pembelian Online Dengan Mediasi Brand Awareness, E-Jurnal Ekonomi \& Bisnis, Volume 09, Nomor 04, Tahun 2020, hlm. 361.

${ }^{17} I d, 364$. 
Berkaitan dengan peraturan perundang-undangan mengenai periklanan, peneliti ngacu pada UU Penyiaran dan PP LIP. Berdasarkan Pasal 46 Ayat 3 UU Penyiaran diatur bahwa "siaran iklan niaga dilarang melakukan halhal yang bertentangan dengan kesusilaan masyarakat dan nilai-nilai agama". Lebih lanjut, berdasarkan Pasal 1 UU Penyiaran, pengertian iklan niaga merujuk iklan komersial melalui penyiaran radio atau televisi. Padahal dengan perkembangan teknologi, iklan tidak hanya dilakukan pada media radio atau televisi tetapi merabah ke media sosial dan hal ini menjadi potensi yang besar di era digitalisasi. Kemudian Berdasarkan Pasal 44 PP LIP, setiap iklan tentang pangan tidak boleh bertentangan dengan norma-norma kesusilaan dan ketertiban umum. Pengertian pangan hanya merujuk pada makanan atau minuman. Dengan kata lain iklan disini terbatas hanya pada iklan produk barang saja dan tidak termasuk produk jasa. Dapat disimpulkan dari kedua aturan ini tidak ada pengaturan khusus terkait iklan di media sosial.

Turunan dari UUPK, Pasal 67 Peraturan BPOM menyatakan bahwa, "Pelaku usaha dilarang mencantumkan pernyataan, keterangan, tulisan, gambar, logo, klaim dan/atau visualisasi keterangan yang menimbulkan gambaran/persepsi yang bertentangan dengan norma kesusilaan, etika, atau ketertiban umum". Menurut peneliti, pasal tersebut tidak tegas menyatakan "letak" untuk mencantumkan "pernyataan, keterangan....bertentangan dengan kesusilaan, etika, atau ketertiban umum". Tetapi jika melihat pasal tersebut diantaranya merujuk definisi tagline baik dalam merk atau iklan.

Pengaturan tentang media sosial di Indonesia, salah satunya ada dalam UU ITE. Berdasarkan Pasal 27 Ayat 1 UU ITE tentang perbuatan yang dilarang, "Setiap Orang dengan sengaja dan tanpa hak mendistribusikan dan/atau mentransmisikan dan/atau membuat dapat diaksesnya Informasi Elektronik dan/atau Dokumen Elektronik yang memiliki muatan yang melanggar kesusilaan". Peneliti berpendapat bahwa pelaku usaha yang membuat akun di media sosial dan mentransmisikan informasi meskipun untuk promosi (menyerbarluaskan informasi produk) baik berupa tagline yang bermuatan kesusilaan masuk dalam ketentuan pasal tersebut. Dengan demikian bila peneliti gambarkan uraian tagline merek yang mengandung unsur pornografi berdasarkan peraturan di Indonesia yaitu sebagai berikut:

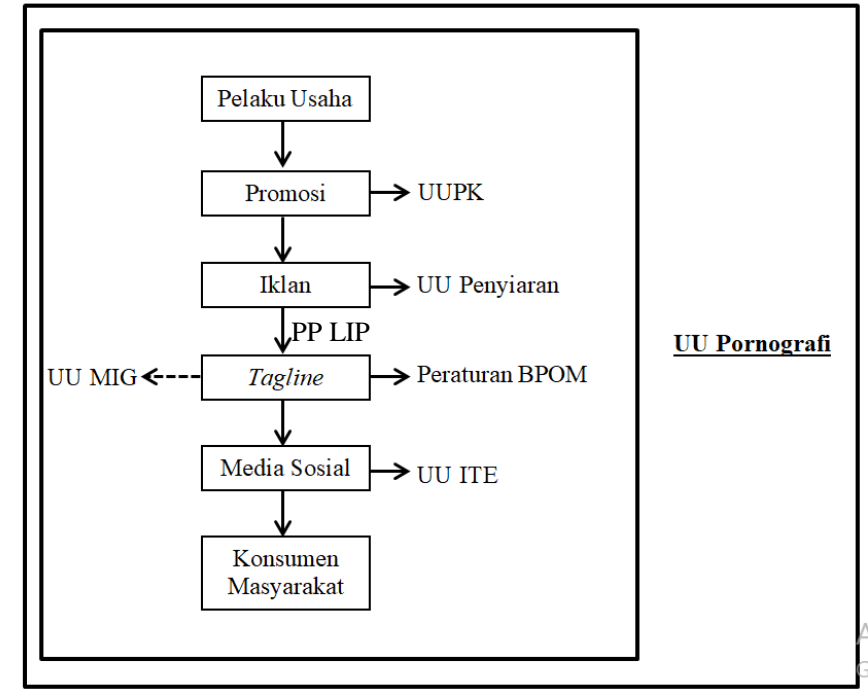

\section{HASIL DAN PEMBAHASAN}

Pengaturan tentang tagline merek yang mengandung unsur pornografi di media sosial.

Sebelum peneliti membahas tentang tagline merek yang mengandung unsur pornografi di media sosial, peneliti akan membahas tentang batasan pornografi menurut UU Pornografi, Black's Law Dictionary dan KBBI. Berdasarkan perbandingan diantara ketiganya, UU Pornografi memiliki makna yang lebih sempit dibandingkan dengan Black's law Dictionary dan KBBI, hal ini terlihat dalam Pasal 4 Ayat 1 UU Pornografi yang menyatakan bahwa pornografi harus dinyatakan secara eksplisit atau berwujud secara tegas, terang-terangan atau gamblang. Dengan kata lain, pornografi dan pelanggaran hukum terkait dengan pornografi baru bisa ditindak dan dianggap melanggar hukum bila secara eksplisit menunjukkan hal-hal yang berbau porno. Namun dalam kenyataan penggunaan bahasa memang tidak secara eksplisit menyatakan hal-hal porno, namun menyiratkan hal itu. ${ }^{18}$

Sejalan dengan pernyataan diatas, ditemukan beberapa perbuatan yang menimbulkan persepsi atau gambaran dan lebih jauh dapat membangkitkan gairah seksual (implisit). Tidak sedikit pula hal ini digunakan sebagai daya tarik dalam suatu produk. Misalnya merk dagang "ngocok es kopi", kata ngocok berasal dari kata kocok yang berarti guncang. Tidak ada yang salah dengan penggunaan kata tersebut, jika hanya dilihat dari struktur bahasa mengingat hal yang lumrah pembuatan es kopi dilakukan dengan proses "kocok" (make a sense). Meskipun tidak sedikit pula masyarakat yang sudah mengamsumsikan kata "ngocok" berkonotasi negatif merujuk pada masturbasi atau onani.

Tetapi akan berbeda bila merek dagang "ngocok es kopi" disandingkan dengan logo atau gambar "tangan

18 Agnes Adhani, Analisis Penggunaan Bahasa, Kandungan Pornografi Dan Konotasi Pornografi, Serta Kandungan Pendidikan Karakter Dalam Teks Lagu Campursari, Jurnal Bebasan, Volume 6 Nomor 1 Tahun 2019, hlm. 4. 
ngocok gelas kopi”. Lebih lanjut, merek dagang tersebut menambahkan tagline atau slogan dalam kemasan produknya, seperti: "tegang? ngocok aja dulu", "mau ngocok atau dikocokin", "ngocok bikin ketagihan", "ngocok sama mantan katanya lebih berkesan" dan "80 Juta, bisa ngocok berapa kali". Tagline terakhir diduga merujuk pada kasus prostitusi yang dilakukan oleh artis Indonesia berinsial VA pada tahun 2019, yang menerima uang sejumlah 80 juta. ${ }^{19}$ Jika dilihat secara keseluruhan, permasalahan tersebut sudah memberikan gambaran/persepsi yang bertentangan dengan kesusilaan (pornografi secara implisit) atau sudah merujuk pada pengertian pornografi dari Black's Law Dictionary dan KBBI. Sayangnya hingga saat ini, ketentuan UU Pornografi menyatakan bahwa kategori pornografi harus terwujud secara eksplisit.

Berkaitan dengan hal diatas, tagline atau slogan adalah serangkaian kata membentuk kalimat bermakna yang dibuat dengan tujuan menarik perhatian konsumen sebagai salah satu upaya promosi yang dilakukan oleh pelaku usaha. Penempatan tagline selalu beriringan dengan merek pada suatu produk tertentu. Misalnya merek dagang "ngocok es kopi", kata "ngocok" pasti disebut dalam setiap tagline yang dibuat. Dengan kata lain, tagline melekat erat (tidak terpisahkan) dari merek produk yang ditawarkan oleh pelaku usaha kepada konsumen. Sehingga dapat disimpulkan bahwa tagline pada suatu merek dapat memberikan ciri pembeda dengan merek lainnya yang tersebar di pasaran. Dari pernyataan tersebut, tagline menampakkan salah satu unsur yang ada dalam ketentuan Pasal 1 Angka 1 UU MIG. Sayangnya hingga saat ini, tagline tidak masuk unsur pada ketentuan tersebut. Sehingga apabila suatu merk tertentu menggunakan tagline yang mengandung unsur pornografi, tidak termasuk dalam "kategori merek yang tidak dapat didaftarkan". Dengan kata lain bisa diterima bila didaftarkan. Padahal dalam praktek, ciri pembeda suatu produk diterima menjadi satu kesatuan atau secara keseluruhan (baik merek maupun taglinenya) oleh konsumen. Berdasarkan e-Penelusuran HKI pada Pangkalan Data KI Indonesia, peneliti menemukan bahwa merek "Ngocok Es Kopi" dengan Nomor Pendaftaran IDM000787366 20 dan Logo "tangan Ngocok Gelas Kopi" dengan Nomor Pendaftaran IDM000786638 ${ }^{21}$ telah lolos dan mendapatkan

${ }^{19}$ Supra note 1.

20 Diakses Pada Laman Pangkalan Data Kekayaan Intelektual, $\quad$ E-Status, DJKI, https://pdkiindonesia.dgip.go.id/index.php/merek/N1JUTldEY0tCMlhQY 0ZNTndpMmJCdz09?q=ngocok+es+kopi\&type $=1$

21 Diakses Pada Laman Pangkalan Data Kekayaan Intelektual, E-Status, DJKI, https://pdkiindonesia.dgip.go.id/index.php/merek/OWlKczZWSytiQy9nN D10K0h5QjhnUT09?q=ngocok+es+kopi\&type=1 perlindungan dari DJKI, sementara untuk merek dengan warna masih dalam proses pemeriksaan Kasubit ${ }^{22}$.

Senada dengan UU MIG, berdasarkan Pasal 12 Ayat 1 Huruf a Peraturan BPOM, nama dagang (merek dagang berdasarkan UU MIG), tidak dapat digunakan bila bertentangan dengan ketentuan peraturan perundang-undangan, moralitas agama, budaya, kesusilaan, dan/atau ketertiban umum. Dengan kata lain, Peraturan BPOM sudah sejalan dengan UU MIG meskipun ada perbedaan penggunaan istilah nama dagang dan merk dagang.

Peraturan BPOM justru memberikan pengaturan yang merujuk tentang definisi "tagline". Hal tersebut terdapat pada Pasal 67 Peraturan BPOM menyatakan bahwa, "Pelaku usaha dilarang mencantumkan pernyataan, keterangan, tulisan, gambar, logo, klaim dan/atau visualisasi keterangan yang menimbulkan gambaran/persepsi yang bertentangan dengan norma kesusilaan, etika, atau ketertiban umum". Menurut peneliti, terlihat adanya overlapping tentang pengaturan "nama dagang" Pasal 12 Ayat 1 Huruf a dengan Pasal 67 Peraturan BPOM. Hal ini terlihat dalam Pasal 12 Ayat 1 Huruf a Peraturan BPOM menggunakan istilah nama dagang atau merk dagang yang merujuk pada UU MIG, dimana UU MIG menyatakan bahwa definisi merk diantaranya berupa logo dan gambar, tetapi justru di Pasal 67 Peraturan BPOM dibahas kembali. Dari sini pula, peneliti melihat adanya korelasi erat antara merek (logo, gambar) dengan tagline (pernyataan, keterangan, tulisan) yang menjadi satu kesatuan. Dengan demikian bila tagline masuk dalam definisi merk, artinya Pasal 12 Ayat 1 Huruf a dan Pasal 67 Peraturan BPOM bisa digabungkan menjadi satu pasal.

Peraturan BPOM merupakan peraturan turunan dari UUPK. Sebagaimana yang telah dijelaskan diatas, tagline merupakan salah satu sarana promosi. Pasal 1 UUPK memberikan definisi tentang promosi yaitu kegiatan penyebarluasan informasi terkait produk yang ditawarkan untuk menarik minat konsumen. Penyebaran informasi ini dapat dilakukan dengan media iklan. Lebih lanjut Pasal 17 UUPK pun mengatur ketentuan bahwa pelaku usaha periklanan dilarang memproduksi iklan yang melanggar etika dan peraturan perundangundangan di bidang periklanan. Sementara mengacu pada Pasal 46 Ayat 3 UU Penyiaran dan Pasal 44 PP LIP, intinya iklan dilarang melakukan hal-hal yang bertentangan dengan kesusilaan. Sayangnya definisi dari iklan niaga hanya mencangkup radio dan televisi saja. Padahal dewasa ini penyebarluasan informasi dapat dilakukan dengan berbagai cara, salah satunya di media sosial. Peneliti berpendapat bahwa penggunaan kata "pelaku usaha periklanan" dalam UUPK memberikan kerancuan mengingat dengan kecanggihan teknologi

22 Diakses Pada Laman Pangkalan Data Kekayaan Intelektual, $\quad$ E-Status, DJKI, https://pdkiindonesia.dgip.go.id/index.php/merek/Z2JyZFc2QVAvd2FZQ XI2b2wrT0IxUT09?q=ngocok+es+kopi\&type $=1$ 
pelaku usaha dapat membuat iklan sendiri (misalnya hanya dengan membuat akun di media sosial).

Salah satu ketentuan tentang media sosial terdapat dalam Pasal 27 Ayat 1 UU ITE, "Setiap Orang dilarang dengan sengaja dan tanpa hak mendistribusikan dan/atau mentransmisikan dan/atau membuat dapat diaksesnya Informasi Elektronik dan/atau Dokumen Elektronik yang memiliki muatan yang melanggar kesusilaan". Peneliti berpendapat bahwa pelaku usaha yang membuat akun di media sosial dan mentransmisikan informasi yang bermuatan kesusilaan masuk dalam ketentuan pasal tersebut meskipun tujuannya untuk kegiatan promosi. Hal ini bisa terlihat dalam akun @ngocok.eskopi, dimana bila dilihat secara keseluruhan mulai dari merk, tagline dan video singkat yang diposting pada media instagram telah memberikan gambaran atau persepsi yang bertentangan dengan kesusilaan.

\section{Upaya apa yang dilakukan oleh pemerintah untuk mencegah tagline merek yang mengandung unsur pornografi di media sosial.}

Berdasarkan UU Pornografi, pemerintah dapat melakukan pencegahan pembuatan, penyebarluasan, dan penggunaan pornografi dengan cara melakukan pemutusan jaringan termasuk pemblokiran pornografi melalui internet, melakukan pengawasan, melakukan kerjasama koordinasi dengan berbagai pihak baik dari dalam maupun luar negeri serta mengembangkan sistem informasi edukasi dalam rangka pencegahan pornografi. Sayangnya, definisi pornografi dalam UU Pornografi memiliki ruang lingkup yang sempit dan pornografi harus terwujud secara ekplisit. Bila dikaitkan dengan permasalahan tagline merek yang mengandung unsur pornografi di media sosial, tidak bisa ditindak lanjuti, mengingat muatan tersebut dibuat secara terpisah - pisah (merek, tagline, video singkat) sehingga tidak menunjukkan adanya unsur eksplisit. Tetapi jika dilihat secara keseluruhan (dalam sudut pandang konsumen), akan terlihat adanya pornografi secara implisit.

UUMIG, pencegahan yang dilakukan oleh pemerintah adalah menolak pendaftaran merek yang mengadung unsur kesusilaan, apabila merek yang mengadung unsur kesusilaan terlanjur terdaftar maka harus dimintakan rekomendasi kepada menteri untuk melakukan penghapusan. Sayangnya tagline bukan termasuk definisi merk dalam UU MIG. Sehingga permasalahan tagline merek yang mengandung unsur pornografi, tidak masuk dalam ketentuan ini. Padahal dalam praktek, konsumen melihat tagline dan merek melekat erat menjadi satu kesatuan sebagai ciri pembeda dari produk yang ditawarkan pelaku usaha. Kenyataannya Merk "Ngocok Es Kopi" dengan logo "Tangan Ngocok Gelas Kopi" lolos dalam pendaftaran di DJKI, padahal jika dilihat secara keseluruhan (include tagline) produk tersebut telah merujuk pada tindakan pornografi secara implisit dan masih beroperasi ditengah-tengah masyarakat.
Berdasarkan UUPK, UU Penyiaran dan Peraturan BPOM tidak ada pengaturan yang khusus mengenai upaya pencegahan terhadap tagline merek yang mengadung unsur pornografi. (semua hanya terbatas pada ketentuan tentang larangan saja). Sementara berdasarkan PP LIP terdapat pengaturan tentang pengawasan iklan yaitu terdapat dalam Pasal 45 Ayat 3 PP LIP "Untuk kepentingan pengawasan, penerbit, pencetak, pemegang izin siaran radio atau televisi, agen dan atau medium yang dipergunakan untuk menyebarkan Iklan dilarang merahasiakan identitas, nama dan alamat pemasang Iklan. Sekilas dapat dipahami bahwa pengawasan ini hanya terbatas pada iklan (televisi, radio) dengan jenis produk barang saja. Tetapi yang penting dipahami adanya frase "dilarang merahasiakan identitas, nama dan alamat pemasang iklan". Dewasa ini dengan perkembangan teknologi, media sosial kerap digunakan sebagai sarana promosi iklan, seseorang bisa dengan mudah membuat akun dengan identitas samaran. Seharusnya syarat pembuatan akun media sosial pun menggunakan identitas yang legal seperti didunia nyata, misalnya Kartu Tanda Penduduk (selanjutnya disingkat KTP).

UU ITE tidak secara spesifik memberikan aturan terkait masalah tersebut. Tetapi pada turunan UU ITE yaitu Peraturan Menteri Komunikasi dan Informatika Nomor 19 Tahun 2014 tentang Penanganan Situs Internet Bermuatan Negatif (selanjutnya disingkat Permenkom PSIBN). Berdasarkan peraturan tersebut, salah satu jenis situs bermuatan negatif adalah pornografi. Pemerintah dapat melakukan pemblokiran terhadap situs bermuatan negatif dalam wadah bernama TRUST ${ }^{+}$Positif. Masyarakat pun dapat turut serta dalam hal tersebut yaitu dengan cara aduan konten. Situs ini merupakan fasilitas pengaduan konten negatif baik berupa situs/website, URL, akun media sosial, aplikasi mobile, dan software yang memenuhi kriteria sebagai Informasi dan/atau Dokumen Elektronik bermuatan negatif sesuai peraturan perundang-undangan. Setiap orang berhak untuk menyampaikan pengaduan konten negatif dengan cara mendaftarkan diri, mengunggah tautan (link) serta screenshot situs atau konten yang dilaporkan disertai alasan, dan memantau proses penanganan yang dilakuan oleh Tim Aduan Konten. ${ }^{23}$ Dengan kata lain, Permenkom PSIBN ini sudah memberikan fasilitas untuk melaporkan situs bermuatan negatif (pornografi) khususnya pada akun mediasosial. Peneliti melihat adanya upaya pemerintah untuk melakukan pencegahan tentang hal-hal yang mengandung unsur pornografi. Permenkom PSIBN ini merujuk pada UU Pornografi, dimana menurut peneliti defisini pornografi dalam undang-undang tersebut harus berwujud secara eksplisit. Jika dikaitkan dengan akun @ ngocok.eskopi, pornografi digambarkan secara implisit yang digunakan dalam praktek berbisnis. Selain 
itu nyatanya merek Ngocok Es Kpoi telah lolos daftar merek karena berdasarkan UU MIG tagline tidak masuk dalam definisi merek. (masih ada hambatan antar aturan).

Dewasa ini banyak sekali media sosial yang dijadikan sebagai sarana promosi (iklan). Sudah seharusnya syarat pembuatan akun di media sosial menggunakan KTP, dimana identitas pengiklan dilarang untuk dirahasiakan (disamarkan). Hal ini sejalan dengan apa yang diatur dalam PP LIP. Pada akhirnya sebisa mungkin identitas dunia maya harus sama dengan identitas legal di dunia nyata, sebab KTP merupakan identitas yang sering digunakan untuk kepentingan bisnis seperti membayar pajak, pendaftaran merek, izin usaha dan lainnya. Terlebih lagi Indonesia telah menerapkan sistem E-KTP. Di era digitalisasi ini, media sosial merupakan media yang potensial untuk mempromosikan kegiatan bisnis, sehingga seharusnya bisa diatur secara khusus seperti pengaturan iklan (konvensional).

Perkembangan teknologi sudah mengubah tatanan sosial masyarakat, interaksi tidak hanya dipandang dalam ruang konvensional tetapi lebih luas tanpa batas yaitu dalam ruang virtual. Hukum senyatanya harus bisa bergerak lebih cepat dibandingkan perubahan yang terjadi dalam masyarakat seperti apa yang dikatakan oleh Roscoe Pound, law as a tool social engineering. Tetapi juga hukum harus dipandang sebagai suatu sistem.

Berangkat dari Pendapat R. Subekti, sistem adalah suatu susunan atau catatan teratur, suatu keseluruhan yang terdiri dari bagian-bagian yang berkaitan satu sama lain tersusun menurut suatu rencana atau pola hasil dari suatu pemikiran untuk mencapai suatu tujuan. Dalam suatu sistem yang baik, tidak boleh terjadi suatu duplikasi atau tumpang tindih (overlapping) diantara bagian-bagian tertentu. ${ }^{24}$

Sudikno Mertokusumo menjelaskan bahwa hukum merupakan sistem yang berarti bahwa hukum merupakan tatanan dan suatu kesatuan yang utuh yang terdiri dari bagian- bagian atau unsur-unsur yang saling terkait erat satu sama lain. Sistem hukum adalah suatu kesatuan yang terdiri dari unsur-unsur yang mempunyai interaksi satu sama lain dan bekerja sama untuk mencapai tujuan kesatuan tersebut. Suatu sistem hukum yang bergerak seakan melingkar dan saling terkoneksi tanpa adanya jeda-jeda yang dapat menjadikan hambatan dalam bekerjanya hukum dalam suatu sistem. Agar tercapainya dan bergeraknya suatu sistem hukum, maka C.F.G. Sunaryati Hartono berpendapat bahwa dibutuhkan suatu organisasi yang dilandaskan kepada asas-asas tertentu. ${ }^{25}$ Dengan kata lain, pada era digitalisasi peraturan perundang-undangan terkait dengan tagline

${ }^{24}$ Rocky Marbun, Grand Design Politik Hukum Pidana dalam Sistem Hukum Pidana Indonesia, Berdasarkan Pancasila dan Undang-Undang Dasar Republik Indonesia 1945, Hlm. 569.

${ }^{25}$ Id, Hlm. 568. merek yang mengandung unsur pornografi di mediasosial harus saling terintegrasi menjadi satu kesatuan dan tidak tumpang tindih.

\section{SIMPULAN}

Praktek berbisnis, merek dijadikan sebagai tanda yang membedakan produk yang satu dengan produk lainnya. Merek memiliki nilai ekonomis sehingga diperlukan adanya perlindungan. Perlindungan merek baru akan timbul ketika merek tersebut telah didaftarkan. Tetapi hal ini dikecualikan terhadap merek yang mengandung unsur kesusilaan. Pada kenyataannya banyak pelaku usaha yang menggunakan merek dengan kata, logo ditambah tagline yang mengandung unsur pornografi. Permasalahannya terlihat jika merek tersebut tetap beroperasi ditengah-tengah masyarakat bahkan merambah ke media sosial. Pengaturan tentang tagline merek mengandung unsur pornografi di media sosial tidak diatur secara khusus tetapi tersebar diberbagai peraturan perundang-undangan dan terlihat adanya overlapping. Hal ini terjadi karena pesatnya perkembangan teknologi yang telah merubah tatanan sosial dalam kehidupan masyarakat. Sementara hukum cenderung statis meskipun tidak dapat dipungkiri hukum mengikuti perubahan yang ada dan mengeluarkan peraturan baru, tetapi pada kenyataannya peraturan tersebut belum terintegrasi antara peraturan yang satu dengan peraturan lainnya.

Pengaturan yang tidak terintegrasi tersebut diantaranya: Pertama, UU Pornografi memberikan batasan pornografi secara eksplisit, sementara banyak kasus pornografi yang terjadi dilakukan secara implisit. Kedua, UU MIG tidak memasukkan unsur tagline ke dalam definisi merek, padahal tagline merupakan unsur yang bisa memberikan ciri pembeda terhadap suatu produk dan keberadaannya selalu beriringan (melekat) pada suatu merek tertentu. Konsekuensi yang bisa terjadi manakala tagline yang digunakan pelaku usaha mengandung unsur pornografi, tetapi mereknya dapat lolos untuk didaftarkan. Padahal bila dilihat secara keseluruhan antara merek (nama, logo dan tagline) yang digunakan terlihat adanya rangkaian tindakan pornografi secara implisit. Ketiga, Peraturan BPOM juga mengatur hal yang sama dengan UU MIG, sayangnya isilah yang digunakan berbeda (nama dagang, merek dagang). Selain itu, Peraturan BPOM pun mengatur tentang tagline tetapi rumusan pasalnya menyebut juga kata, logo, gambar yang merujuk pada definisi merek. Oleh sebab itu, peneliti mengasumsikan bahwa kenyataannya tagline dan merek adalah dua hal yang saling melekat dan memjadi ciri yang khas dalam suatu produk. Keempat, bila berbicara tentang tagline maka akan sangat berhubungan dengan promosi. Berdasarkan UUPK promosi diartikan sebagai penyebarluasan informasi tentang produk yang ditawarkan. Promosi biasanya dilakukan dengan media iklan. Lebih lanjut UUPK mengatur tentang iklan, dimana pelaku usaha 
periklanan dilarang memproduksi iklan yang bertentangan dengan peraturan perundang-undangan dan etika periklanan. Peneliti melihat adanya frase "pelaku usaha periklanan" yang dirasa sudah tidak pas dengan kondisi saat. Kelima, berkaitan dengan periklanan berdasarkan UU Penyiaran yang disebut dengan iklan niaga hanya merujuk pada media radio dan televisi. Pengertian ini juga dirasakan kurang pas, mengingat pelaku usaha bisa membuat iklan sendiri di media sosial. Media sosial merupakan media promosi yang potensial dalam dunia bisnis saat ini. Keenam, UU ITE telah memberikan pengaturan informasi bermuatan kesusilaan di media sosial, lebih lanjut ada upaya pemerintah untuk melakukan pomblokiran. Artinya aksesnya diputus, permasalahan muncul jika pelaku usaha tersebut membuat akun akun baru untuk promosi hal serupa, mengingat batasan UU ITE hanya terbatas "jaringan media sosial" sementara merek berserta taglinenya masih bisa beroperasi ditengah-tengah masyarakat. Dengan demikian perlu adanya integrasi antara peraturan yang satu dengan peraturan lainnya mengingat kini bisnis sudah masuk dalam tatanan digitalisasi.

\section{DAFTAR PUSTAKA}

Agnes Adhani, Analisis Penggunaan Bahasa, Kandungan Pornografi Dan Konotasi Pornografi, Serta Kandungan Pendidikan Karakter Dalam Teks Lagu Campursari, Jurnal Bebasan, Volume 6 Nomor 1 Tahun 2019.

Derby Juliana Osak, et.all., Pengaruh Brand Ambassador Dan Tagline Terhadap Keputusan Pembelian Online Dengan Mediasi Brand Awareness, E-Jurnal Ekonomi \& Bisnis, Volume 09, Nomor 04, Tahun 2020, hlm. 361.

https://aduankonten.id/

Hwain Cristiano, Norma Kesusilaan sebagai Batasan Pornografi menurut UU No. 44 Tahun 2008, Jurnal Hukum Pembangunan Tahun ke-40 No.1 Januari-Maret 2010.

Iffan Alif Khoironi, Implementasi Pendaftaran Merk Sebagai Bentuk Perlindungan Hukum Pada Home Industry Eegroll, Unnes Law Journal Volume 2 Nomor 2, Tahun 2013.

Rahmadia Maudy Putri Karina, et.all., Perlindungan Hukum Bagi Pemegang Hak Merek Dagang Ikea Atas Penghapusan Merek Dagang, Jurnal Pembangunan Hukum Indonesia, Volume 1, Nomor 2, Tahun 2019.

Rakhmita Desmayanti, Tinjauan Umum Perlindungan Merk Terkenal Sebagai Daya Pembeda Menurut Perspektif Hukum di Indonesia, Jurnal Cahaya Keadilan . Vol. 6. No. 1, Tahun 2018, hlm. 14.

Rocky Marbun, Grand Design Politik Hukum Pidana dalam Sistem Hukum Pidana Indonesia, Berdasarkan Pancasila dan Undang-Undang Dasar Republik Indonesia 1945.
Sulastri, et.all., Perlindungan Hukum Terhadap Merek (Tinjauan Terhadap Merek Dagang Tupperware Versus Tulipware), Jurnal Yuridis Vol. 5 No. 1, Juni 2018.

Sultan Himawan, Representasi Pornografi Pada Media Sosial (Analisis Semiotika Pierce Pada Aplikasi Bigo Live), MediaKom Jurnal Ilmiah Ilmu Komunikasi, Volume 8 Nomor 1, 2018.

Suratman et.all., Analisis Yuridis Penyidikan Tindak Pidana Pornografi Berdasarkan Undang-Undang Nomor 44 Tahun 2008 di Era Digitalisasi, Jurnal Pembaharuan Hukum Volume I No. 2 Mei Agustus 2014.

Yayuk Sugiarti, Perlindungan Merek Bagi Pemegang Hak Merek Ditinjau Dari Undang-Undang Nomor 15 Tahun 2001 Tentang Merek, Jurnal Jendela Hukum, Volume 3, Nomor 1, April 2016.

Yudha Wirawanda, et.all., Bias Gender dalam Berita Kasus Vanessa Angel (Analisis Wacana Kritis Sara Mills dalam detik.com)., Channel Jurnal Komunikasi, Volume 7, Nomor 1, April 2019.

\section{Website:}

Pangkalan Data Kekayaan Intelektual, E-Status, DJKI, https://pdki-

indonesia.dgip.go.id/index.php/merek/N1JUTldE Y0tCMlhQY0ZNTndpMmJCdz09?q=ngocok+es+ kopi\&type $=1$

Pangkalan Data Kekayaan Intelektual, E-Status, DJKI, https://pdki-

indonesia.dgip.go.id/index.php/merek/OWlKczZ WSytiQy9nND10K0h5QjhnUT09?q=ngocok+es+ kopi\&type $=1$

Pangkalan Data Kekayaan Intelektual, E-Status, DJKI, https://pdki-

indonesia.dgip.go.id/index.php/merek/Z2JyZFc2Q VAvd2FZQXI2b2wrT0IxUT09? $\mathrm{q}=$ ngocok+es+ko pi\&type $=1$ 